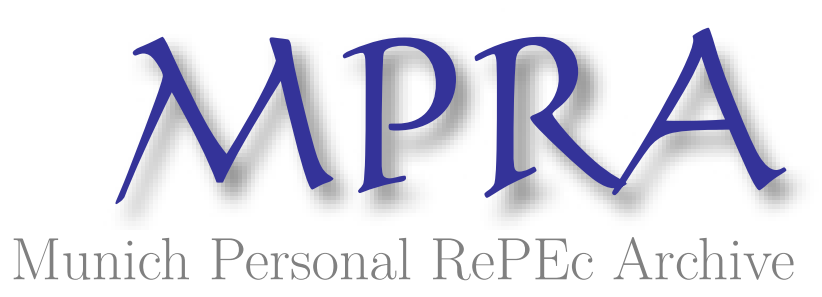

\title{
An Overview of Agricultural Credit and Crop Insurance in Bihar
}

Singh, R.K.P. and Singh, K.M.

R.A.U., Bihar, ICAR-RCER, Patna

9 January 2013

Online at https://mpra.ub.uni-muenchen.de/46901/

MPRA Paper No. 46901, posted 11 May 2013 19:39 UTC 


\title{
An Overview of Agricultural Credit and Crop Insurance in Bihar
}

\author{
R.K.P.Singh ${ }^{1}$ and K.M.Singh ${ }^{2}$
}

Bihar has a large agrarian economy of over Rs 250 billion with more than 80 percent of rural population subsisting on farming. Agricultural work force increased more than two-fold from 126 lakh in 1981 to 265 lakh in 2006 whereas net sown area declined by about one lakh hectares and gross cropped area has been stagnating at 80 lakh hectares during the period. Due to increase in number of agricultural labour force in Bihar, per agricultural worker annual real productivity (at 1980 prices) has declined from Rs 1977.00 in 1980-81 to Rs 1278.00 in 2005-06.

Bihar is characterized by excessive dependence of population on agriculture and dominance of small land holders. Small and marginal farmers constitute about 90 per cent of total farm households whereas farm households owning land less than 0.5 ha constitute 78 per cent of total farm households and their average farm size is about 0.10 hectare.

The agricultural production has been showing declining trend during 2001-07 and the income from agriculture is increasingly becoming insufficient to meet even the basic consumption needs of farm households. It is more so far small and marginal farmers whose income falls short of their consumption expenditure.

\section{Credit flow in the State}

In this situation, the majority of farm households don't have savings to invest in critical inputs such as irrigation, seed, fertilizer and agricultural chemicals. Institutional agricultural credit is the only option which can help in increasing investment in agriculture through improving the liquidity of the farmers for using critical inputs at proper time. The financial requirement of farmers has increased manifold due to adoption of modern technology. Keeping in view the increasing demand for agricultural loan in Bihar, the National Bank for Agricultural and Rural Development (Regional office, Patna) also increased their projection for agricultural credit in the State from Rs 1745 crore in 2001-02 to Rs 5720 crore in 2008-09 and Rs. 8427 crore in 2009-10. Even if the target set for agricultural credit is achieved, it will still be less than two third of per hectare agricultural loan made

\footnotetext{
${ }^{1}$ University Professor (Retd.), Department of Agricultural Economics, Rajendra Agricultural University, Bihar, Pusa, Samastipur

${ }^{2}$ Principal Scientist and Head, Division of Socio-Economics and Extension, ICAR-RCER, Patna-14

Lecture delivered in the Training Programme on "Agriculture and Environment" organized by BIPARD, Patna and held at ICAR-RCER, Patna from 09 to 13 Jan 2013.
} 
available to farmers at national level and less than 50 percent of loans granted in agriculturally advanced states in the country. As per National Sample Survay Organization (NSSO), only 17.2 per cent rural households in Bihar obtained institutional credit in 1971 which declined to 14.3 per cent in 2003, the remaining majority households (86\%), mainly small and marginal farmers, have virtually no access to institutional source of credit in the State. Proportion of non- institutional loanees to total indebted farmers increased from 43 per cent in 1991 to 75 per cent in 2003 as against 49 per cent and 54 per cent, respectively at the national level.

Institutional bankers perform a gap-filling function in Bihar whereas the situation is just reverse in other parts of the country. Among the major states in India, Bihar is at the lowest ladder in terms of proportion of institutional loan to total loan disbursement to farmers. The high indebtedness to money lenders may be an important reason for indifferent attitude of farmers towards lending institutions, resulting in low investment and low productivity in Bihar.

Provision of credit to agriculture sector has been one of the main concerns of policy planners in India since independence. However, an assessment of the situation at ground level indicates that recourse to non-institutional credit continues to dominate as far as rural areas and agriculture sector are concerned. Institutional credit expanded with slow growth rate during 1980-81 to 1990-91 when it took 10 years in doubling the amount of credit in Bihar. The similar growth pattern was observed during 1990-91 to 1999-2000 when it increased from Rs 231.81 crore to Rs 477.12 crore during the period. The growth in agricultural credit remained slow upto 2002-03 when total amount of agricultural credit could hardly reach Rs 1587 crore. The farm credit package announced in June 2004 stipulating doubling institutional credit flow to agriculture during the following three years seems to have worked in Bihar as well. Although agricultural credit flow in the state increased from Rs 1587 crore in 2003-04 to Rs 2985 crore in 2006-07, and Rs 3700 crore in 2007-08, the base itself was very low. But the share of agricultural credit flow in Bihar to national level agricultural credit flow declined from 1.82 percent in 2003-04 to 1.47 per cent in 2006-07. It clearly indicates that the institutional credit system in Bihar failed to perform on par with systems functioning in other parts of the country.

The expansion of commercial banks has been impressive in post- nationalization period but per commercial bank branch rural population increased from 50,000 in 2002 to 66,000 in 2008 in Bihar. There are 24 block headquarters in Bihar which are still unbanked.

The co-operative system is still an important source of agricultural credit in Bihar. In spite of several drawbacks, co-operatives continue to be a highly favoured agency for financing agricultural and allied activities. The Bihar State Co-operative Land Development Bank was established to cater to 
the needs of long-term agricultural credit but it has been in recurrent loss for the last 13 years and the bank does not qualify for any assistance from NABARD due to poor recovery performance. The short-term co-operative credit structure has Bihar State Cooperative Bank at the apex level. At the middle level, the state had originally 25 District Central Co-operative Banks (DCCBs) of which license applications of 3 were rejected in 2003, reducing the number to 22 with 279 branches. There were only 12 profit making DCCBs in Bihar in 2005-06 and the majority of DCCBs experienced deposit erosion from 50 to 100 per cent and none of the bank qualifies for audit classification of 'A'. The poor financial performance of DCCBs is reflected in their inability to respond to the increasing demand for agricultural credit in Bihar.

The majority of Primary Agricultural Cooperative Credit Societies (PACS) (69 per cent) are nonviable, and about 1,000 PACS are non-functional in Bihar. Their ability to disburse credit has deteriorated due to weak financial strength. The Task Force on Restructuring of Cooperative Credit Institutions (2005) underlined the need to eliminate State Government interference in the functioning of co-operatives and recommended a revival package for retiring the share capital contribution to cooperative societies. The State Government initiated the implementation of the Task Force recommendations but progress is still slow as compared to most of the states in the country. The Government of Bihar has, however, amended the cooperative act and constituted an organization for conducting election of co-operative institutions. A campaign has also been launched by State Government for increasing membership of PACS. Besides, Government has already launched Integrated Co-operative Development Projects (ICDP) in 8 districts for improving infrastructure, diversification of activities and making available required funds to PACS. There are, however, still large numbers of interested farmers who are being denied PACS membership by concerned PACS officials. The State Government should take suitable steps to involve left-over farmers under cooperative movement initiated in the State. An effective monitoring of the implementation of ICD Project needs to be done for rational utilization of funds for faster agricultural development in Bihar.

But the strengthening of co-operatives under different programmes may not by itself solve the problem of farmers because even the viable and profit making PACS are not assigning priority to agricultural credit and the majority of these PACS are engaged mainly in banking business. It is therefore, suggested that PACS officials be sensitized to adopt empathetic and pro-farmer attitude towards agricultural development.

Before reorganization of Regional Rural Banks (RRBs), there were 17 RRBs in Bihar, covering all the districts of the State. Since their inception in 1975 the RRBs have grown rapidly in structure and strength. During period, the financial performance of RRBs was much better than rural branches of 
commercial banks but RRBs failed to maintain their edge over rural branches of commercial banks and were caught in trap of high NPA $(46.45 \%)$ and poor recovery (34.13). Due to financial weakness, RRBs could disburse only Rs 75 crore of loans in 2001-02 but increased the level of disbursement to Rs 431 crore in 2005-06. Regional Rural Banks have large network of branches in rural area of Bihar and they can play a significant role in agricultural financing. NABARD reviewed the performance of RRBs and suggested quality lending by RRBs but failed to spell out details of quality lending in the report. However, the hassle-free credit disbursement to financially viable projects of credit-worthy farmers can solve the problem of increased overdues of Regional Rural Banks in Bihar.

Adequacy of credit- increased flow but way behind national average Adequate agricultural credit is a pre-requisite for increasing agricultural production. Per hectare agricultural loan granted in Bihar (Rs 882) was the lowest among major States of the country and much lower than the national average of Rs 3386 in 2000-01. Per hectare agricultural loan disbursement in Bihar increased from Rs 882 in 2000-01 to Rs 4814 in 2006-07.

However, the increase at national level has been from Rs 3306 to Rs 11363 during the period. If the projected agricultural credit of Rs 571998 lakh is achieved in Bihar during 2008-09, per hectare agricultural loan would be Rs 9225 which will still be about 25 percent less than the average national achievement of 2006-2007.

Kisan Credit Card (KCC) has emerged as the most import instrument of disbursement of agricultural rural credit in the country. At national level, about 77 percent of farm households have been provided Kisan Credit Cards for hassle-free credit disbursement. Andhra Pradesh and Kerala took lead in making available KCC to more than 90 percent of their farmers. Government of Bihar also initiated special campaign in 12 districts in early 2008-09 but could issue KCC to only 2.5 lakh farmers in first six months of 2008-09. However, a special campaign for issue of Land Possession Certificate (LPC) as well as for issue for KCC has already been launched in December, 2008 which shall continue to be organized every month. If target for providing $\mathrm{KCC}$ to additional 15 lakh farmers is achieved by the end of year 2009, about 35 per cent of farm households will get KCCs in Bihar which will still be about half of the national average.

The tempo generated by the first series of Mega Camps at Block headquarters needs to be sustained and even accelerated. The campaign for issue of $\mathrm{KCC}$ to farmers should continue during the entire period of Eleventh Five Year Plan so that all eligible farm households in Bihar are covered. 


\section{Self Help Groups (SHGs)}

Self Help Groups (SHGs) are emerging as organizational innovations for providing thrift-linked credit support, particularly to weaker sections of the rural society. The SHG institutions not only benefit their members, they also enable banks to reduce their transaction costs and risks in delivering small loans. This also improves banks' outreach and credit flow to the poor. The recovery under SHG-Bank linkage programme has been impressive at national level: $90 \%$ for commercial banks, $87 \%$ for RRBs and $86 \%$ for co-operative banks' in 2005-06. During the last 15 years, there has been phenomenal increase in the number of SHGs.

Some 29 lakh credit-linked SHGs have so far been established upto 2007 in the country. Bihar accounts for 8 per cent of national population but more than 18 per cent rural poor of the country reside in the state. Only 2.46 per cent of SHGs of country have been established in the State upto 2007. Although substantial number of SHGs has been promoted by various agencies during last two years, all the eligible SHGs have not been credit-linked in Bihar. Out of 10716 SHGs organized by Women Development Corporation, Bihar, 7786 SHGs have been linked to Micro-financing institutions but only 2990 are credit-linked. Given the poverty level in the state, predominance of small and marginal farmers as well as landless labourers in Bihar, SHGs have tremendous potential in lifting the disadvantaged groups and rescuing them from poverty trap.

This assumes particular significance and urgency in view of the difficulties being faced in accessing credit from the institutional sources in Bihar. Andhra Pradesh accounts for nearly 50 per cent of SHGs promoted in the entire country. On the lines of Andhra Pradesh, Federation of SHGs needs to be promoted for further strengthening of the SHGs movement in the State. Co-operative should also be involved in formation of SHGs and federations of SHGs through their wide network in villages.

Interest subsidy for increasing agricultural loans despite the initiatives by Central and State Governments, agricultural credit flow is still at the lowest level in Bihar. It is, therefore, further recommended that a large number of Self Help Groups, Joint Liability Groups and Farmers Clubs should be organised in Bihar for increasing agricultural credit flow and reducing transaction cost of borrowing in the State.

Government of Bihar has started reorganization of co-operatives but the process needs to be accelerated so that they start functioning effectively for the benefits of farmers, particularly small and marginal farmers located in remote area who have poor access to other banking institutions.

National Commission on Farmers (NCF) has also suggested strengthening of cooperatives and recommended the reduction of interest rate to 4 per cent per annum for agricultural credit. 
Government of Karnataka has reduced interest rate on agril cultural cooperative loan to 4 percent since 2007 whereas Madhya Pradesh reduced interest rate to 5 percent on short term agricultural credit since 2008. Uttarakhand Government also took initiative for increasing agricultural credit flow and reduced interest rate to different types of agricultural loans for different categories of farmers. In Uttarakhand, small and marginal farmers can obtain co-operative loan on an interest rate of 5 percent, all categories of farmers are now entitled to get co-operative loan of Rs 1 lakh for agriculture and house construction at an interest rate of 5.5 percent whereas tractor loan from cooperatives up to Rs 5 lakh is available to all categories of farmers on 5.5 per cent in Uttarakhand. In these States, agricultural credit flow is much higher than Bihar. Hence, it is recommended that the interest rate on co-operative crop loans should be reduced by 3 per cent in Bihar for benefit of farmers. It will be a motivation to farmers to approach co-operatives for agricultural loan who are still not inclined to contact commercial bank branches. According to 2009-10 projections of NABARD Focus Paper, total crop loans in Bihar through all the three lending agencies (Commercial banks, Regional Rural Banks and Co-operatives) are estimated to be Rs 5074 crore in 2009-10. During the year 2007-08, cooperative could grant only Rs 350 crore of crop loan, accounting for 13.91 per cent of crop loan granted by all the institutional agencies. The co-operative crop loan is likely to increase in the year 2009-10, mainly due to restructuring of co-operatives and implementation of Vaidyanathan Committee recommendations in the State. But the co-operative crop loan may not increase more than Rs 2030 crore which will be 40 per cent of total crop loans granted through all the three lending institutions in Bihar. Due to proposed interest subsidy of $3 \%$ to crop loans granted through co-operatives the total additional liability of the Government is estimated to be Rs 61 crore in 2009-10. Besides interest subsidy, a close co-operation and effective coordination between officials of Government and financing institutional agencies will be required to increase agriculture credit flow in Bihar.

Hence, it is recommended that the interest rate on co-operative agricultural loans should be reduced by 3 per cent in Bihar for benefit of farmers. It will motivate farmers to approach cooperatives for agricultural loans who are still not inclined to contact commercial bank branches.

According to 2009-10 projections of NABARD Focus Paper total crop loans in Bihar through all the three main lending agencies (Commercial banks, Regional Rural banks and Co-operatives) will be Rs 5074 crore in 2009-10. During the year 2007-08, co-operative could grant only Rs 350 crore of crop loans, accounting for only 13.91 per cent of crop loans granted by all the institutional agencies. The co-operative crop loan is likely to increase in the year 2009-10, mainly due to restructuring of co-operatives and implementation of Vaidyanathan Committee in the State. But the co-operative 
crop loan may not increase more than Rs 2030 crore which will be $40 \%$ of crop loans granted through all the three lending institutions in Bihar. Due to proposed interest subsidy of $3 \%$ to crop loans granted through co-operatives the total additional liability of the Government is estimated to be Rs 61 crore in 2009-10.

\section{Agricultural Insurance}

Agricultural insurance offers protection against losses caused by fluctuations in the output of a crop from one year to another or from one crop season to another. Its objective is to stimulate and support the production of principal crops in the country. Providing financial support to farmers in the event of crop failure, it makes farmers credit-worthy for the next crop season. It has been observed that the majority of small and marginal farmers, as well as tenant farmers and farm labourers bear the brunt of crop failure. In 1979-80, a pilot crop insurance scheme was launched in limited areas in 12 states. In April 1985, a comprehensive crop insurance scheme was implemented which covered all the willing states and Union Territories. It was implemented in 17 states and 2 Union Territories up-to kharif 1990. The benefits of this crop insurance were extended to nearly 1.94 million farmers and covered 3.41 million hectares. However, the scheme covered mainly large farmers but small farmers did not get benefits of the scheme.

The benefit of the comprehensive crop insurance scheme was availed by farmers of Gujarat, Maharashtra, Andhra Pradesh and Madhya Pradesh. Their share was nearly 90 percent of the claims paid in the country during 1985-90. Bihar, Assam and north-eastern states lagged behind in availing the benefits of crop insurance. The share of these states was less than 1 percent of total claims paid in the country (Singh 1993)

In the year 1999-2000 the Government of India in co-ordination with the General Insurance Corporation of India (GIC), had introduced a new scheme namely; the National Agricultural Insurance Scheme (NAIS) from Rabi 1999-2000 season. The main objective of the scheme was to protect the farmers against losses suffered by them due to crop failure on account of natural calamities, drought, flood, hail storm, cyclone, pest and diseases, so as to restore their credit worthiness for the ensuing season. Agricultural Insurance Company of India Ltd. (AICIL) which was incorporated in December, 2002 and started operating from April, 2003 took over the implementation of NAIS.

In Bihar, National Agricultural Insurance Scheme is implemented in all the districts of Bihar. However, insurance of cash crops is implemented in some selected districts where these crops are grown on large scale. Loanee and non-loanee farmers including share croppers and tenant farmers are eligible for insuring their crops under this scheme. However the coverage is compulsory for 
loanee farmers and optional for non-loanee farmers. Farmers can insure their crops for 150 percent of value of their crops by paying actuarial rate of premium.

The performance of National Agricultural Insurance Scheme has also been unsatisfactory in Bihar. During 1999-2005, total claims of Rs. 68.20 billion was paid to farmers in the country but only Rs. 2.90 billion of insurance claims was paid to farmers in Bihar, accounting for only 4.24 percent of total claims paid in the country during the period (Table-19). Gujarat, Karnataka, Maharashtra and Andhra Pradesh performed much better in insuring crops of their farmers and about 69 per cent insurance claims paid in the country was paid in these four states. These states have done well in insuring crops of their farmers in comprehensive crop insurance scheme in nineties also. Despite change in form of crop insurance scheme and establishment of Agricultural Insurance Company Ltd. the regional disparity in crop insurance still persists in the country.

Table-1: State wise crop insurance claims paid to farmers in major states of India during Rabi 1999-2000 to Kharif 2005

\begin{tabular}{|l|l|l|}
\hline State & $\begin{array}{l}\text { Claims Paid } \\
\text { (in Rs. Crore) }\end{array}$ & Percentage to Total \\
\hline Bihar & 28970 & 4.24 \\
\hline Gujarat & 194728 & 28.51 \\
\hline Karnataka & 97157 & 14.23 \\
\hline Maharashtra & 76744 & 11.24 \\
\hline Andhra Pradesh & 99515 & 14.57 \\
\hline Other States & 185814 & 27.20 \\
\hline India & 682938 & 100.00 \\
\hline Source: - Progress document, Agricultural Insurance Company of India Ltd. (AICIL), 2007 \\
\hline
\end{tabular}

\section{Progress of crop insurance}

In 2001-02, about 0.78 per cent of farmers were covered under crop insurance scheme in Bihar against 8.86 per cent farmers in the country. However, the proportion of farmers covered under the scheme increased to 3.93 per cent in Bihar, whereas at national level the proportion increased to 13.91 per cent in 2005-06. The proportion of coverage of farmers under scheme has been much lower in rabi season in Bihar as well as in India but it increased to 1.81 percent in Bihar and 3.39 percent in India in the year 2005-06 (Table-2). 
Table-2: Number of farmers and their cropped area covered, sum assured and total claims paid in crop insurance in Bihar Vs India during 2001-06.

\begin{tabular}{|c|c|c|c|c|c|c|c|c|c|c|c|c|}
\hline \multirow[t]{2}{*}{ Particulars } & \multicolumn{2}{|c|}{ Kharif 2001} & \multicolumn{2}{|c|}{$\begin{array}{l}\text { Rabi } \\
\text { 2001-02 }\end{array}$} & \multicolumn{2}{|c|}{$\begin{array}{l}\text { Kharif Rabi } \\
\text { 2001-02 }\end{array}$} & \multicolumn{2}{|c|}{$\begin{array}{l}\text { Kharif } \\
2005\end{array}$} & \multicolumn{2}{|c|}{$\begin{array}{l}\text { Rabi } \\
\text { 2005-06 }\end{array}$} & \multicolumn{2}{|c|}{$\begin{array}{l}\text { Kharif Rabi } \\
\text { 2005- } \\
06\end{array}$} \\
\hline & Bihar & India & Bihar & India & Bihar & India & Bihar & India & Bihar & India & Bihar & India \\
\hline $\begin{array}{l}\text { No. of } \\
\text { farmers } \\
\text { covered } \\
\text { (in lakh) }\end{array}$ & 0.52 & 87 & 0.29 & 20 & 0.81 & 107 & 2.21 & 127 & 1.88 & 41 & 4.09 & 168 \\
\hline $\begin{array}{l}\% \text { farmer } \\
\text { household } \\
\text { covered }\end{array}$ & 0.5 & 7.20 & 0.28 & 1.66 & 0.78 & 8.86 & 2.13 & 10.51 & 1.81 & 3.39 & 3.93 & 13.91 \\
\hline $\begin{array}{l}\text { Area } \\
\text { covered } \\
\text { (lakh ha) } \\
\end{array}$ & 0.56 & 129 & 0.33 & 32 & 0.89 & 161 & 2.27 & 205 & 2.30 & 72 & 4.57 & 277 \\
\hline $\begin{array}{l}\text { sum } \\
\text { assured } \\
\text { (Rs. Crore) }\end{array}$ & 47.96 & 7503 & 24.82 & 1450 & 72.78 & 8953 & 339.1 & 13518 & 284.40 & 5070 & 623.50 & 18588 \\
\hline $\begin{array}{l}\text { Premium } \\
\text { collected } \\
\text { (Rs. Crore) }\end{array}$ & 1.20 & 262 & 0.38 & 30 & 1.58 & 292 & 8.58 & 449 & 4.38 & 105 & 12.96 & 554 \\
\hline $\begin{array}{l}\text { Total } \\
\text { claims } \\
\text { paid (Rs. } \\
\text { Crore) }\end{array}$ & 1.83 & 494 & 1.37 & 65 & 3.20 & 559 & 14.9 & 1055 & 53.04 & 252 & 67.94 & 1307 \\
\hline
\end{tabular}

The coverage of cropped area under the scheme was much lower in Bihar (1.0\%) in 2001-02 which increased to 5.13 percent in $2005-06$. The coverage at country level was comparatively high $(8.43 \%)$ in 2001-02 which increased to 14.51 percent in 2005-06. In Bihar sum assured was Rs. 72.78 crore in 2001-02, accounting for about 0.8 percent of sum assured at country level (Rs 8953 crore). However, the sum assured under the scheme increased to Rs.623.50 crore in Bihar and Rs. 18588 crore in India in 2005-06 and Bihar's share in sum assured in the country increased to 3.35 percent. Due to risk prone agriculture, about 10.90 percent of sum assured was paid as claim to farmers in Bihar against 7.03 percent at country level, indicating higher risk prone agriculture in Bihar. Despite risk-prone agriculture and increase in coverage, only 4.09 lakh farmers benefited from crop insurance in Bihar in 2005-06. It calls for a massive campaign for increasing crop insurance coverage for mitigating risk in Bihar's agriculture. 
Analysis of farm category-wise data revealed that the proportion of marginal and small farmers in total farmers participating in crop insurance is 83 percent against their proportion of 96 percent in total farm households in Bihar (Table-3).

Table-3: Category-wise farmers covered under crop insurance scheme in Bihar (2006-07)

\begin{tabular}{|l|l|l|l|}
\hline Sl. No. & Type of farmers & No. of Farmers & (in '000) \\
\hline & & Kharif 2001 & Kharif 2006 \\
\hline 1.0 & S/M Farmers & $50.65(100)$ & $292.95(100.00)$ \\
\hline 1.1 & Loanees & $50.62(99.94)$ & $285.17(97.34)$ \\
\hline 1.2 & Non-Loanees & $0.03(0.06)$ & $7.78(2.66)$ \\
\hline 2.0 & Other Farmers & $0.97(100.00)$ & $51.74(100)$ \\
\hline 2.1 & Loanees & $0.97(100.00)$ & $27.57(53.29)$ \\
\hline 2.2 & Non-Loanees & - & $24.17(46.71)$ \\
\hline 3.0 & Total Farmers & $51.62(100.00)$ & $344.69(100)$ \\
\hline 1.1 & Loanees & $51.59(99.94)$ & $312.74(90.73)$ \\
\hline 1.2 & Non- Loanees & $0.03(0.06)$ & $31.95(9.27)$ \\
\hline Figures in parentheses indicate percentage to respective totals. \\
\hline
\end{tabular}

The subsidy of 50 percent to the premium paid by small and marginal farmers may be the reason for the coverage of a large number of these categories of farmers on record under crop insurance scheme. Moreover, per farmer coverage of crop area of about 1.12 ha under the scheme clearly indicates low level of participation of marginal farmers whose upper limit of holding is one hectare. Non-loanee farmers are also permitted to get their crops insured but very few of non-loanee farmers participated in crop insurance in Bihar in the year 2001. In Kharif 2006, about 32 thousand nonloanee farmers got their crop insured but their proportion was 9.27 percent of total farmers participating in crop insurance in Bihar. However only 2.66 percent of total participating small and marginal farmer in crop insurance scheme belonged to non-loanee category whereas 46.71 percent non-loanee farmers of medium and large categories could get their crop insured in kharif 2006 in Bihar.

It is accordingly recommended that a campaign be launched in rural areas to create awareness among farmers about crop insurance involving, inter alia, non-loanee farmers because a large number of farmers are still not in a position to avail crop loan facility from institutional agencies in Bihar.

\section{Coverage of Crops}

In Bihar, principal food grains, potato, onion rapeseed/ mustard and sugarcane are covered under crop insurance scheme. In 2006-07, about 12.18 percent rice area and 19.2 percent of wheat area were covered whereas only 0.63 percent area under pulses, 0.60 percent area under onion and 0.18 percent rapeseeds/mustard were covered in Bihar in 2006-07 (Table-4). This clearly indicates that the 
comparatively high proportion of less risk prone crops (wheat) and less proportion of high risk prone crops (onion, rapeseed/mustard and pulses) were covered in Bihar. The popularity of credit linked crop insurance might be the reason for less coverage of pulses and oilseeds under crop insurance in Bihar because the use of purchased inputs in pulses and oilseeds is comparatively low in Bihar and farmers do not approach financing agencies for loans in cultivating these crops. Hence, there is low insurance coverage of these crops in Bihar. The coverage of these crops insurance can only be increased by popularizing scheme for non-loanee farmers.

Table-4: Number of farmers and their area of principal crops covered under crop insurance in Bihar (2006-07)

\begin{tabular}{|l|c|c|c|}
\hline Crops & Number of Farmers & Area Covered (ha) & \% crop area insured \\
\hline Paddy & 335426 & 414555 & 12.18 \\
\hline Pulses & 6744 & 3799 & 0.63 \\
\hline Gram & 645 & 950 & 1.58 \\
\hline Arahar & 3058 & 2175 & 7.25 \\
\hline Lentil & 3041 & 3799 & 2.37 \\
\hline Maize & 12535 & 15298 & 2.35 \\
\hline Onion & 592 & 313 & 0.60 \\
\hline Potato & 14286 & 7766 & 7.30 \\
\hline Rapeseed/Mustard & 222 & 182 & 0.18 \\
\hline Sugarcane & 6216 & 7494 & 6.10 \\
\hline Wheat & 299030 & 378821 & 19.20 \\
\hline \multicolumn{2}{|r|}{ Source: Agriculture Insurance Company of India Limited, Patna (Bihar) } \\
\hline
\end{tabular}

In Bihar, about 40 percent value of total crop output is generated through fruits and vegetables but only a few vegetable crops namely; potato and onion are covered under crop insurance. Moreover, vegetables are generally grown by small and marginal farmers and these crops are more risk-prone than food grains and other crops covered in Bihar. None of the fruits is covered under insurance in Bihar. In Japan, even fruit trees are covered under insurance. Livestock and fisheries sectors also contribute more than 40 percent to agriculture GDP in Bihar but the negligible coverage of only purchased livestock is done through General Insurance Company. Fisheries and poultry production are still to be covered under insurance.

\section{Role of Credit Institutions}

All the three rural financing institutions that is; Co-operative Banks, Regional Rural Bank and Commercial banks are engaged in crop insurance scheme. Commercial banks granted about 56 percent of crop loans but covered only 16 percent of farmers under crop insurance in Bihar in 200506 (Table-5). 
Table-5: Share of different lending institutions in granting crop loans and their share in coverage of farmers in Bihar. (2005-06) (\%)

\begin{tabular}{|l|l|l|}
\hline Name of Bank & Share in crop loan & Share in crop insurance \\
\hline Commercial Banks & 56 & 16 \\
\hline Gramin Banks & 21 & 21 \\
\hline Co-operatives & 23 & 63 \\
\hline
\end{tabular}

On the other hand, co-operatives granted 23 percent of total crop loans disbursed by all the three financing institutions in Bihar but covered about 63 percent of total farmers participating in crop insurance in Bihar in the year 2005-06 (Map-VI). Regional rural banks granted about 21 percent of crop loans in Bihar and covered 21 percent of participating farmers. Among Commercial Banks, Punjab National Bank performed much better in crop insurance than other Commercial Banks operating in Bihar.

Despite compulsory insurance of notified crops in notified area for loanee farmers, commercial banks failed in providing insurance facilities to all their crop loanees. The co-operatives with their weak infrastructure performed much better in providing crop insurance facilities to farmers in Bihar.

Progress of agricultural insurance has been slow in Bihar since the inception of the scheme. The main reasons of slow growth are inadequate flow of crop loan, indifferent attitude of commercial banks, and weak financial health of Co-operatives and non-inclusion of vegetables, fruits and spices crops in crop insurance scheme. Besides these factors, lack of awareness about crop insurance among farmers and inadequate publicity about the scheme is also affecting adversely the expansion of the crop insurance scheme in Bihar.

In Bihar, crop damage by wild animals is now emerging a major menace. Such cases may be sporadic and in selected pockets but causes substantial crop loss to a large number of farmers. Like some developed countries namely; Japan and Korea, there is an urgent need to develop a project of crop insurance for insuring crop loss due to wild animals.

Above discussions clearly indicate that there is vast scope for extending insurance support to a large number of loanee and non-loanee farmers for various crops. The process of agricultural insurance needs to be accelerated to save the weaker sections of society because the majority of small and marginal farmers as well as tenant farmers and farm labourers bear the brunt of crop failures. Therefore, the target group for preferential treatment should consist of small and marginal farmers, as well as tenant farmers and farm labourers. 


\section{Weather-based crop Insurance}

In 2007-08, the weather-based crop insurance scheme (WBCIS) was implemented in the selected areas of Karnataka on pilot basis. WBCIS intends to provide insurance protection to farmers against adverse weather incidence such as deficit and access rainfall which are deemed to impact adversely the crop production. It has advantage to settle claims within the shortest possible time. The BWCIS is based on actual rates of premium but to make the scheme attractive, premium actually charged from farmers has been restricted to at par with NAIS. The Agriculture Insurance Company of India Ltd. (AICIL) has implemented weather based crop insurance scheme in three districts (Patna, Muzaffarpur and Araria) during 2007-08 and paid claim of Rs 170.16 lakh to farmers in May 2008. In Rabi season 2008-09, all the blocks of five districts (Patna, Muzaffarpur, Gaya, Bhagalpur and Purnea) are covered for Wheat, Lentil, Gram and Potato under WBCIS. Crop area covered under the scheme is less than one percent of total area of respective crops grown in Bihar. The scheme seems to be beneficial for farmers and it should be expanded to all the blocks for all the principal crops including vegetables and fruits.

In crop insurance, block for rice and wheat, and district for other crops are declared "units" for estimating crop losses in Bihar. However, districts and blocks do not have homogeneous agroeconomic \& geographical situations. Despite the higher yield of a crop in a particular district, some villages of the district have low yield due to localised natural calamities and farmers of these villages are denied crop insurance benefit in this situation. Panchayat should be declared as unit for crop insurance to meet this type of situation. The State Government should take necessary steps so that Panchayat is declared as unit for crop insurance of all the crops in Bihar. 